\title{
El regreso siempre posible a Dios y al hermano. La conversión en Jeremías
}

\author{
Rafael de Sivatte, \\ Centro de Reflexión Teológica, \\ San Salvador.
}

\section{Introducción}

En el mundo actual es importante tratar el tema del perdón y de la reconciliación y, además, tratarlo tal como se han desarrollado en la tradición judeo-cristiana. Vivimos, en efecto, en un mundo que, por una parte, está muy influenciado por esa tradición, y, por otra, está desgarrado y desangrado por guerras a causa de motivos religiosos, culturales, étnicos, económicos, ideológicos, etc. Además, las divisiones sociales entre los empobrecidos y los enriquecidos producen grave injuslicia y heridas difíciles de sanar. Egoísmos e intereses espúreos producen marginación de mujeres, indigenas, campesinos, niños de la calle, prostitutas, miembros de pandillas callejeras, enfermos de sida, etc. Por último, ese mundo no piensa en cuidar la naturaleza para que ésta siga siendo en el futuro la habitación digna y confortable para nuestros descendientes.

Por todo lo dicho, bien podemos decir que Dios y la humanidad se sienten ofendidos y tratados injustamente, y por eso exigen conversión. Sin embargo, en la tradición judeo-cristiana ésta no es la última palabra: se ofrece también perdón y reconciliación.

Para ilustrar ese proceso de condena, exigencia de conversión y ofrecimiento de perdón, en este artículo me voy a centrar en la figura de Jeremías, uno de los grandes profetas de Israel y de la tradición cristiana, que más han profundizado en la realidad del pecado y de la conversión, y en la posibilidad de regresar a Dios y al hermano, por muy alejada que a veces se encuentre una persona de cllos. Más aún, la relación Dios-persona humana aparecerá como modelo de la relación entre los seres humanos.

Comenzaremos con una breve presentación de la persona de Jeremías, analizaré después su visión de la realidad y del pecado histórico, su llamada 
constante a la conversión y su convicción de que es posible el perdón y la oferta de nueva alianza. Constataremos al final, que esta buena noticia no es recibida frecuentemente con alegría por quienes ya se sienten satisfechos, sino que provoca una respuesta de persecución y de muerte. Es el destino del profeta.

Y digamos para terminar esta introducción, que la misión y el destino del profela Jeremías son recurrentes en la historia, como lo muestran Monseñor Romero y Rutilio Grande en El Salvador, Mons. Gerardi en Guatemala, y tantos otros profetas-mártires de la fe y de la justicia.

\section{Breve presentación del profeta}

Jeremías era natural de Anatot, pueblo perteneciente a la pequeña provincia de Benjamín, a caballo entre los dos reinos, el de Israel (ya desaparecido en tiempo de Jeremías) y el de Judá. Políticamente, fue muchas veces dependiente de la vecina Jerusalén, mientras que religiosamente el mayor influjo provenía de las tradiciones del norte, las que hacen referencia a la salida de Egipto. En el año 628 a. C., año de la vocación de Jeremías, Anatol, como todo el reino de Israel, era una provincia de Asiria. El vecino reino de Judá, en cambio, scguía gozando por aquel entonces de una cierta independencia.

Un personaje importante en Anatol era Jilquías, ministro-sacerdote del santuario dedicado al Dios Yahveh. A pesar de la dependencia de Asiria, Jilquías, otros más, y debido a la manera de ser del pueblo israelita, había contribuido a mantener, en parte, la propia idiosincrasia tradicional, cultural y religiosa del antiguo reino de Israel, y en concreto, de las pequeñas aldeas y pueblos que habían conformado la antigua provincia de Benjamín.

Jeremías fue uno de los hijos de Jilquías. De joven gustaba, al parecer, de la vida sencilla $y$ de relaciones humanas agradables. Dada su timidez y sensibilidad humana, prefería escuchar lo que otros querían compartir que hablar él de su visión de la realidad, de sus preocupaciones o sentimientos. Por otra parte, el hecho de que su padre ejerciese como sacerdote del santuario del pueblo hizo que Jeremías estuviera familiarizado con el trato personal con el Dios Yahveh y se preguntara con frecuencia qué debía sentir Yahveh ante las dilíciles relaciones con su pueblo.

En el año 628 a. C., Jeremías sintió que Yahveh, el Dios que había liberado de Egipto a sus antepasados, le llamó a ser su profeta con la misión de "arrancar y plantar", de "derribar y construir", de denunciar y anunciar. Jeremías se resistió desde el principio, y se excusó muchas veces, aduciendo que no tenía experiencia, que era torpe de palabra, que no tenía autoridad moral para que le hicieran caso: excusas todas ellas, aunque comprensibles, para no aceptar una misión que veía dificultosa, llena de posibles tensiones y fuertes sufrimientos. Pero. a pesar de ello, en una siluación de dependencia internacional, e. 
internamente, de injusticia social, opresión económica, egoísmo de los poderosos, violencia, alienación religiosa y el intento de manipulación de Dios, empezó su acrividad profética.

No le costó mucho al principio, pues coincidió con un clima de euforia y esperanza en la cercana Jerusalén, en los primeros años de la reforma del joven rey Josías (633 a 622 a.C.). Jeremías pudo, pues, predicar un mensaje positivo: a pesar de su infidelidad a Dios y de la opresión al hermano. Dios seguía invitándoles a abandonar el pecado. Llamó entonces al pueblo a un cambio radical de actitudes para volver al ideal del amor y la comunión. Finalmente, les anuncia una buena noticia: Dios se compromete al perdón, apuesta de nuevo a su favor $y$, sobre todo, pondrá en su interior su ley para poder vivir según su voluntad y construir una nueva sociedad ( $\mathrm{Jr} 2,3,30$ y 31 ).

Tras esta primera actividad ocurrió algo muy importante, que determinó la vida y destino de Jeremías. En el año 622 a. C., cuando llegó a su culmen la reforma de Jośas, el culto se centralizó en el templo de Jerusalén y se destruyeron todos los santuarios populares a su alrededor. El padre de Jeremías tuvo que trasladarse con toda su familia a Jerusalén, lo cual supuso un cambio importante para el tímido Jeremías. Al principio no parece que tuviera que ejercitar una actividad profética, pero a la muerte del rey Josías cambiaron las cosas. Impuesto por Egipto, le sucedió su hijo Joaquín I, quien eliminó los aspectos positivos de la reforma de Josías y sólo mantuvo lo que le podía ayudar a gobernar sin protestas a un pueblo maltratado. En concreto, se sirvió de la centralidad del templo de Jerusalén desde el cual podía manipular el culto a Yahveh al servicio de sus intereses.

La sensibilidad humana y religiosa de Jeremías no lo pudo soportar. Volvió a sentir la llamada de Yahveh, y ahora para una misión desagradable y difícil. Inició as! su segunda actividad, que se extendio durante los años del reinado de Joaquín I, es decir, desde el 609 hasta el 598 a. C., aunque en los tres 6 cuatro últimos años de este reinado parece que tuvo que mantenerse oculto, dada la fuerte persecución que Joaquín I desencadenó en su contra. En su conjunto, esta segunda actividad estuvo caracterizada por un esquema recurrente: fuerte denuncia de la situación, persecución a muerte del profeta, rebelión interna de Jeremías contra Yahveh - ya que se sentía engañado por él- y nuevas denuncias y amenazas.

El ejemplo clásico es lo ocurrido alrededor del discurso sobre el templo (Jr 7). Jeremías amenaza con la destrucción del templo - semejante a la del gran santuario del reino de Israel, Silo-, si continúan los crímenes y la opresión. Sigue el intento de linchamiento, evitado por la intervención de personas de autoridad moral, y un juicio del que salió libre (Jr 26). Después, el profeta se queja duramente contra Yahveh, porque parece estar con los malvados. Dios 
responde augurando mayores dificultades y exigiendo mayor confianza $(\mathrm{Jr} 11,18-12,6)$.

El esquema se repite más adelante. Jeremías anuncia la invasión desde cl norte (Jr 4-6). Es encarcelado, torturado y presionado para que no vuelva a hablar en público (Jr 19. I-20.6). Se rebela de nuevo contra Yahveh y maldice de su propia vida. Yahveh le anuncia mayores dificultades, aunque se compromete a no abandonarlo ( $\mathrm{Jr}$ 15, 10-21). Dicla a su compañero Baruc —para que las lea en público- nuevas denuncias y amenazas. Su escrito es confiscado y destruido por el rey; Baruc y él mismo tienen que esconderse para evitar ser asesinados. Jeremías vuelve a redaclar una nueva versión clandeslina de su escrito (Jr 36). En su escondile, vuelve a maldecir el día en que nació y a rebelarse contra Yahveh. Intenta retirarse de la misión, pero no lo hace, pues, en último término. siente que Yahveh está a su lado y lo sigue interpelando para que hable en su nombre (Jr 20, 14-18.7-13). En 598 a. C., el nuevo rey Sedecías deja en libertad a Jeremías con lo que termina su segunda actividad profética.

De 598 a 593 a. C., existió en Jerusalén un clima de relativa tranquilidad. Pero cuando en el año 593 a. C. resurgen los movimientos de rebelión contra Babilonia, Jeremías inició su tercera actividad. La rebelión no era querida por Yahveh, por el inmenso dolor que producía en el pueblo, y de ahí que Jeremías sc opuso a quienes la impulsaban: algunos ministros del rey, los sacerdotes del templo y los profetas oficiales. Simbólicamente, cargó sobre sus hombros un yugo de madera, que simbolizaba a Babilonia, y cuando un profeta oficial lo quebró, Jeremías lo reemplazó por uno de hierro, anunciando así que —de momento- ésa era la decisión de Yahveh (Jr 27 y 28). También escribió a los que habían sido llevados a Babilonia que no pensasen que el exilio se acabaría pronto, sino que debían prepararse, más bien, para un largo destierro (Jr 29). Por el inomento, consiguió dominar los intentos de rebelión.

Pero la rebelión estalló el año 588. Nabucodonosor alacó de nuevo a Judá y Jerusalén. Jeremías aconsejó durante este tiempo que se negociase la paz, por lo cual muchos lo consideraron como colaborador y iraidor, lo encarcelaron y lo persiguieron a muerte. Jeremías intentó hacerles caer en la cuenta de que debían cvitar lo peor, pero no volvieron atrás y dejaron que la siluación llegase hasta el exiremo (Jr 34, 37, 38). Cuando ya los babilonios estaban a punto de entrar en la ciudad, Jeremías desconcertó al pueblo con un acto simbólico: encarcelado, mandó traer a un notario para comprar formalmente un campo familiar de Anatot (ien momentos en que toda la región estaba asolada por la guerra!), queriendo dar a entender, de parte de Yahveh, que en el futuro se comprarían y venderían campos, que se volverla a la actividad normal (Jr 32). Finalmente la ciudad cayó en manos de Nabucodonosor. Jeremías libre de nuevo, eligió quedarse acompañando a la gente (Jr 39; 40, 1-6), constituyendo ésta su cuarta actividad. 
Poco después, algunos judíos decidieron acabar con el gobernador. Le pusieron una trampa y lo mataron. Su muerte provocó el pánico en gran parte de la población por las posibles represalias de Nabucodonosor, y algunos empezaron a proponer como la mejor solución huir a Egipto. Pidieron a Jeremías que apoyase. de parte de Yahveh, tal propuesta. Jeremías les aconsejó permanecer en la tierra de Judá, pero decidieron irse a Egipto y se llevaron a Jeremías contra su voluntad. Ya en Egipto, Jeremías siguió intentando que su pueblo no se entregase a los dioses egipcios y anunció que, por más seguros que se sintiesen allí, Babilonia invadiría el país y volvería a dominar a judíos y egipcios. Según la tradición. judíos y egipcios se unieran para acabar con la vida del profeta.

De este breve recorrido por la vida y actividad de Jeremías, hay varios aspectos que es conveniente resaltar. En apretado resumen podemos decir que Jeremías se dejó llenar por Yahveh y tuvo una relación muy personal con él. Superó sus timideces y su miedo, gracias a que siempre dejo que Yahveh estuviera a su lado. Se atrevió a discutir con Yahveh sobre lo que le ocurría. pero se puso confiadamente en sus manos y se entregó cada vez con más fuerzia a la misión prolética. Supo ir descubriendo, en la tradición de le y en la variedad de las situaciones que le tocó vivir, qué palabra nueva debía decir en cada momento. Procuró leer siempre las señales de Yahveh en la historia del pueblo para poder pronunciar la palabra que éste quería que pronunciara. ya luera de denuncia, de amenaza, de exhortación a la conversión, de esperanza. Sufrió en su propia carne el dolor de Yahveh por la infidelidad del pueblo y el Jolor del pueblo fruto de dicha infidelidad. Siempre estuvo preocupado por acompañar al pueblo y por hacerlo sentir que realmente Yaluveh estaba muy cerca. Se volcó totalmente al pueblo, lleno de amor a sus compatriotas, cspecialmente a los más sencillos. Intentó evitar los sufrimientos del pueblo y estuvo siempre dispuesto a ponerse en su lugar y a sufrir para que el pueblo no suliriera.

Esta breve semblanza del profeta la creemos importante para situar mejor el tema específico de la conversión. tal como la comprendió y predicó Jercmías.

\section{Punto de partida: denuncia y desenmascaramiento del pecado}

En la primera actividad, dirigida a sus compaisanos de Anatol y del antiguo reino de Israel, Jeremías les recuerda, en primer lugar, la situación dc enamoramiento de Dios en la liberación del dominio egipcio y en el camino por el desierto hacia la tierra prometida. Jeremías utiliza los términos "cariño juvenil" y "noviazgo". La pregunta que Yahveh hace a Israel es, entonces, por qué sus antepasados no se mantuvieron fieles a él: los sacerdotes no han buscado la presencia de Yahveh, los expertos de la ley no le conocen, los pastores no le son dóciles, los profetas no profetizan en su nombre. En su 
conjunto, todos caminan tras dioses vacíos. Yahveh está perplejo a la vista de lo que nunca ha ocurrido con otros pueblos. Israel ha cambiado la realidad de Dios por un dios vacío, el manantial de aguas vivas por cisternas agrietadas. Yahveh se pregunta, en último término, por qué es ahora esclavo Israel, siendo asi que ha nacido libre. $Y$ la respuesta es porque ha abandonado a $Y$ ahveh, se ha negado a servirle, se ha corrompido, se ha manchado, dejándose lascinar por los imperios, se ha dejado ganar por los ídolos, se ha cerrado a las continuas llamadas de Yahveh, se ha mostrado ingrato, se ha olvidado de su noviazgo, ha asesinado a gente totalmente inocente, se ha declarado inocente cuando, con sus acciones y actitudes, ha demostrado continuamente que no lo es. La conclusión de Yahveh es que Israel sí ha pecado y gravemente (cfr. Jr 2).

En la segunda actividad, la denuncia del pecado, dadas las duras circunstancias por las que atraviesa el país, es mucho más fuerte y concreta. En Jeremías 7, el profeta desenmascara la hipocresla religiosa de Jerusalén, ya que sus habitantes, en especial los miembros de la corte, oprimen al inmigrante, al huérfano y a la viuda; derraman sangre inocente; van tras otros dioses; se lían de palabras engañosas o de fórmulas mágico-religiosas; se sienten seguros; creen poder comerciar la salvación con Dios en el templo; dan culto a otros dioses; ponen los sacrificios y holocaustos por delante del cumplimiento de la voluntad de Yahveh y de la obediencia a las palabras de sus enviados los profetas, cuando en realidad Yahveh nunca ha pedido eso en el momento más fundamental de la formación del pueblo al liberarlo de Egipto; son desleales e infieles; sacrifican a sus hijos a los dioses cuando Yahveh nunca to ha querido.

En esa segunda actividad, ante la cerrazón de muchos, Jeremías comienza a hablar de la invasión desde el norte, analiza los motivos de tal invasión y denuncia: se han rebelado contra Yahveh, están llenos de fechorías (cfr. Jr 4, 17 18), no conocen a Yahveh, son sabios para lo malo e ignorantes para el bien, han convertido toda la tierra en un caos y el cielo en oscuridad, han provocado el fin de la vida, han confiado en el poder y el amor de otros pueblos y sus dioses ( $c f r$. Jr 4, 22-30), no se encuentra en ellos justicia ni verdad, juran en falşo, no quieren aprender, dejan a Dios y juran por quienes no lo son, adulteran, reniegan de Dios y consideran que nada tiene que ver con sus vidas. confían en sus plazas fuertes, ponen trampas a sus prójimos, llenan sus casas de fraude, se enriquecen y engrandecen, ejecutan malas acciones, no juzgan la causa del huérfano, ni sentencian el derecho de los pobres, sus profetas dicen mentira y los sacerdotes se dejan llevar por sus intereses ( $c f r$. Jr 5 ), en la ciudad hay atropello y despojo, golpes y heridas, todos andan buscando su provecho $y$ practican el fraude, los sacerdotes y profetas anuncian la paz cuando no hay paz (cfr. Jr 6). Jeremías, para dar fuerza a estas sus palabras, hace el acto simbólico público de la ruptura del jarro (cfr. Jr 19) para expresar la destrucción de la ciudad de Jerusalén y da como razón que sus habitantes dejan a Yahveh y van tras otros dioses totalmente desconocidos, y sus reyes llenan la ciudad de sangre 
de inocentes, construyen altares a Baal para quemar a sus hijos. Y en Jeremías 36. ante la imposibilidad de seguir hablando, el profeta decide diclar sus palabras a Baruc para que él las lea en el templo: toda la casa de Judá va por Inal camino y está llena de culpa y de pecado. Siempre, por tanto, el punto de partida de la actividad de Jeremías es la situación de pecado del pueblo de Dios, una siluación que se refiere a las relaciones con Dios y con el prójimo.

También en la tercera actividad, en torno a los años 593-588 a. C., cuando cl rey Sedecías se siente tentado por la potencia egipcia y presionado por algunos ministros, sacerdotes y proletas a rebelarsc contra Babilonia, Jeremías sc las tiene que ver con ellos y, de nuevo, su punto de partida es la constatación clel pecado del que no quieren salir. En las palabras a los reyes (cfr. Jr $21.1-23$, 8 ), en las que les recuerda cuál es su función religiosa y social, les denuncia su lálsa seguridad ("Ustedes que dicen: ¿Quién se nos echará encima? ¿quién entrará en nuestras guaridas?'", Jr 21, 13); su abandono de la alianza de Dios y la adoración o servicio a otros dioses ( $c f r$. Jr 22,9 ) -en el caso concreto del rey Joaquín l-, su injusticia, su derramamiento de sangre inocente, sus atropellos (cfr. Jr 22, 13-17) —en el de Joaquín Il一, su cerrazón a escuchar la voz de Dios y su disposición a escuchar las voces de sus amanles (cfr. Jr 22, 21.23), y - linalmentc, en el caso de Sedecías - su descuido de las ovejas a su cuidado ( $c f r$. Jr 23, 2), su incoherencia con el significado de su nombre, que hacc relerencia a la salvaguarda de la justicia social ( $c f r$. Jr 23,6 ).

En las palabras a los profetas que animan a la rebelión contra Babilonia, el punto de partida es también la denuncia de sus actitudes, su fornicación, su lalta de rectitud, su impiedad, su maldad, su falsedad, su connivencia con los malhechores, su corrupción, su mal ejernplo, sus engaños, su incumplimiento del deber, sus halagos a los malvados, sus invenciones, sus irresponsabilidades, sus imposturas, su contribución a los errores del pueblo, su inutilidad (cfr. Jr 23, 9-40). Y en Jeremías 27-29, donde el profeta se enfrenta abiertamente al mensaje de falsa seguridad que están dando los falsos profetas, cuando dicen que Babilonia ya está vencida y que en poco tiempo van a regresar a la tierra los deportados en el año 598 a. C. y con ellos todos los objelos del templo que Nabucodonosor se ha llevado a Babilonia, la denuncia del profela consiste en que las palabras de aquéllos se basan en la falsedad, en la convicción de que todo va bien y que Judá no tiene nada de qué convertirse, en la autosuficiencia, en la concepción de un Dios manipulable y sobre el que se tiene derechos.

Finalmente, en la últina actividad de Jeremias, acompañando a su puchlo destrozado en Judá y aconsejándolo después en Egipto, la base del mensaje del prolela vuelve a ser la denuncia y el desenmascaramiento de todas sus actitudes falsas e idolálricas. Esto lo vemos con claridad en los últimos años, tal como aparece en Jeremías 44, 4ss cuando por boca del profeta Yahveh dice: 
Yo me afané por enviarles todos mis siervos los profetas, a decirles:

"Ea, no hagan esta abominación que detesto". Pero no oyeron ni aplicaron el oído para convertirse de su malicia y dejar de incensar a otros dioses... ¿Por qué se hacen ustedes tanto daño a ustedes mismos, hasta borrarse a hombre y mujer, niño y lactante de en medio de Judá sin que les quede resto, irrilándome con las hechuras de sus manos... y acabar en tema de maldición y oprobio en todas las naciones de la tierra? ¿Si será que han olvidado las maldades de sus padres y las de los reyes de Judá... y las propias de ustedes y las de sus mujeres; maldades que hacían en tierra de Judá y en las calles de Jerusalén?

Todo lo anterior no es más que el punto de partida de la actividad de Jeremías, aunque nos indica ya que el pecado que denuncia hace referencia a las relaciones con Dios y con el prójimo. Un punto de partida que parecería concluir que Dios no puede perdonar y que lo único que puede hacer es pedir cuentas a su pueblo (cfr. Ir 5, 7.9). Sin embargo, no es así. Inmediatamente sigue la exhortación a la conversión, basada en la convicción de que es posible el perdón y la reconciliación.

\section{Exhortación a la conversión: una conversión a Dios y al hermano}

En la printera actividad, entre los años 628 y 622 a. C., dirigida a sus compaisanos de Anatot y alrededores, el profeta descubre cómo Dios, a pesar de que el pecado y la actitud posterior de Israel parecen cerrar las puertas a una conversión, a un perdón y a una nueva relación, sigue queriendo la conversión y llama por medio del profeta a la misma, tal como lo vemos en Jeremías 3, 1213: "Vuelve, Israel apóstata; no estará airado mi semblante contra ustedes, porque piadoso soy y no guardo rencor para siempre. Tan sólo reconoce lu culpa, pues contra Yahveh tu Dios te rebelaste, frecuentaste extranjeros bajo todo árbol frondoso..."; en Jeremías 3, 22: "Vuelvan, hijos apóstatas; yo remediaré sus apostasías"; en Jeremías 4, 1-2: "Si volvieras, Israel... si a mí volvieras, si quilaras tus monstruos abominables y de mí no huyeras. jurarías 'por vida de Yahveh' con verdad, con derecho y con justicia, y se bendecirían por él las naciones y por él se alabarían". Y en medio de las palabras de restauración de Jeremías 30-31, el profeta presenta al pueblo como el que está dispuesto a reconocer sus lallos y a hacer caso de la llamada de Yahveh a la conversión. Así lo dice Yahveh:

Bien he oído a Efraím lame*...drse: "Me corregiste y corregido fui, cual becerro no domado. Hazme volver y volveré pues tú, Yahveh, eres mi Dios. Porque luego de desviarme, me arrepiento, y luego de darme cuenta me golpeo el pecho, me avergüenzo y me confundo luego, porque aguanto el oprobio de mi mocedad" (Jr 31, 18-19).

Ante esto, Yahveh insiste y llama de nuevo a su pueblo diciendo: 
"Plántate hitos, ponte jalones de ruta, presta atención a la calzada, al camino que anduviste. Vuelve, virgen de Israel, vuelve a estas ciudades. ¿Hasta cuándo darás rodeos, oh díscola muchacha? (Jr 31, 21-22).

En la segunda actividad del profesa, durante el reinado de Joaquín I, es decir, entre los años 609 y 598, son constantes las llamadas de Jeremías a la conversión. El profela, por ejemplo, llama a quienes entran por las puertas del templo a postrarse ante Yahveh y les dice:

Mejoren de conducla y de obras y yo haré que se queden en este lugar... Porque si mejoran realmente su conducta y obras... y no andan en pos de otros dioses para daño de ustedes, entonces... No fíen en palabras engañosas, diciendo: "jiemplo de Yahveh, templo de Yahveh, templo de Yahveh es éste!". Porque si... realmente hacen justicia mutua y no oprimen al inmigrante, al huérfano y la viuda y no derraman sangre inocente en este lugar, ni andan en pos de otros dioses para su daño, entonces... (Jr 7, 3-7).

A continuación, Yahveh les recuerda por medio de Jeremías lo que les mandó al sacarles del país de Egipto: “... cuando yo saqué a sus padres del país de Egipto... les mandé...: 'Escuchen mi voz y yo seré su Dios y ustedes serán ini pueblo y seguirán todo camino que yo les mandare, ...les vaya bien" (Jr 7. 2123).

En Jeremías 26, cuando se resumen partes del discurso del capítulo 7 , Yahveh encarga a Jeremías que hable a todas las ciudades de Judá todas las palabras que él le ha mandado hablarles. Y Yahveh continúa diciendo: "Puede que oigan y se torne cada cual de su mal camino, y yo me arrepentiría del mal que estoy pensando hacerles por la maldad de sus obras". A raíz de este discurso se da un intento de acabar con Jeremías y se lo llega a juzgar, pidiendo la pena de inuerte. En el juicio, Jeremías, en su defensa, dice: "Yahveh me ha enviado a profetizar sobre esta Casa y esta ciudad todo lo que han oído. Ahora bien, mejoren sus caminos y sus obras y oigan la voz de Yahveh su Dios y se arrepentirá Yahveh del mal que ha pronunciado contra ustedes" (cfr. Jr 26, 12 13).

Siempre en el marco de la segunda actividad del profeta, en Jeremías 4-6, y dirigiéndose en este caso a Judá, el profela sigue exhortando a cultivar el barbecho y no sembrar sobre cardos, a circuncidarse para Yahveh y extirpar los prepucios de sus corazones ( $c f r$. Jr 4, 3-4), para intentar evitar la invasión del imperio del norte. Judá es llamado a ceñirse de sayal, a lamentarse y a plañer ( $c f r$. Jr 4,8$)$. En medio del poema en que el profeta imagina la invasión. va llamando al pueblo a dicha conversión y a Jerusalén a limpiar de malicia el corazón (cfr. Jr 4, 14). Es más, Yahveh muestra gran pasión por su pucblo al pensar en la invasión y manifiesta en el fondo que no puede soportar que su pueblo caiga, tal como aparece en Jeremías 4, 19-21: “ $¡$ Mis entrañas, mis 
entrañas! ¡Me duelen las telas del corazón, se me salta el corazón del pecho!... porque son saqueadas mis tiendas". En el mismo contexto, en Jeremías 5, 1, el profeta dice que si se encontrase alguien en la ciudad de Jerusalén que practicara la justicia y buscara la verdad, es decir, alguien que se convirtiera, "yo [refiniéndose a Yahveh] la perdonaría". El problema está en que, como añade a continuación, "rehusaron convertirse" (Jr S, 3). En realidad, Yahveh no quiere que los enemigos de Judá acaben con su pueblo ( $c f r$. Jr 5, 10). Una vez más, en Jeremías 6, I6, Yahveh invita a su pueblo a pararse en los caminos y preguntarse por los senderos antiguos, cuál es el camino bueno y andar por él, para encontrar sosiego para sus almas. Esto supone que Yahveh está llamando de nuevo a la conversión.

Estas llamadas a la conversión a Dios y al prójimo prosiguen en Jeremías 25, I-13, donde el profeta comienza a hablar ya de que el invasor del norte tiene un nombre concreto, Babilonia. Ahí recuerda cuál ha sido su mensaje constante:

Ea, vuélvanse cada cual de su mal camino y de sus malas acciones, y volverán al solar que les dio Yahveh a ustedes y a sus padres, desde siempre hasta siempre. No vayan en pos de otros dioses para servirlos y adorarlos, no me provoquen con las hechuras de sus manos, y no les haré mal (Jr 25, 5-6).

En esta unidad recuerda después que no han hecho caso, normalmente, a estas llamadas a la conversión, para acabar diciendo que también a Babilonia le llegará el turno de ser visitada por Yahveh y esto se convertirá en buena noticia para Judá.

Así, pues, en medio de la dificilísima segunda actividad de Jeremías en tiempo del rey Joaquín I, actividad en la que tuvo que denunciar con fuerza la conducta del rey, de sus ministros, de los responsables, etc., frente a los sencillos. a los marginados, a los trabajadores, etc., y en la que tuvo que soportar, en consecuencia, una fortísima persecución a muerte por parte del poder, Jeremías nunca deja de llamar a la conversión a Judá y Jerusalén, con la esperanza de que la situación cambie y entre todos puedan evitar el desastre que ya se puede prever.

Pasando a la tercera actividad del profeta (598-587), en tiempos del rey Sedecías, volvemos a encontrarnos con un Jeremías que sigue llamando a la conversión. Son los momentos en que después de la primera caída de Judá en manos de Babilonia y la imposición de Sedecías como rey, comienzan de nuevo movimientos de rebelión contra Babilonia. Jeremías, en tal circunstancia, sigue insistiendo en el recuerdo de lo que Yahveh espera de Judá $y$, por tanto, llamando de nuevo a la conversión. En primer lugar, lo hace con los reyes a los que en Jeremías 21,11-12 les dice: "Hagan justicia cada mañana y salven al oprimido de mano del opresor, so pena de que brote como fuego mi cólera... a causa de sus malas acciones". Como se ve, en este texto se insiste en que la 
conversión pasa por hacer justicia a los súbditos y liberar al oprimido de manos del opresor. Es Yahveh mismo el que, si no se produce esta conversión al hermano, al prójimo oprimido, tomará partido a favor de éste.

Y en Jeremías 22, 1-3, dirigiéndose también al rey de Judá en la misma línea, pero también a sus servidores y al pueblo entero, leemos:

Practiquen el derecho y la justicia, libren al oprimido de manos del opresor. y al inmigrante. al huérfano $y$ a la viuda no atropellen; no hagan violencia ni derramen sangre inocente en este lugar.

De nuevo, Jeremías llama a la conversión, una conversión que para llegar a Yahveh debe pasar por la realización de la justicia y la práctica de la solidaridad con el tratado injustamente y con el marginado o abandonado.

Oro momento importante es aquel en que Jeremías se enfrenta a los profetas, quienes están animando al pueblo a la rebelión contra Babilonia. Jeremías es de la opinión que esto no tiene ningún sentido y que lo necesario es que dichos profelas llamen más bien a la conversión. Los acusa de que, de hecho. están alienando y enajenando al pueblo con falsas esperanzas y que la rebelión triunfará. La única salida posible consiste en, según Jeremías. convertirse de nuevo a Yahveh y volver a ser un pueblo unido y fuerte.

Vcamos el texto de Jeremías 23, 9-40. En el verso 16. Jeremías llama a la gente a no hacer caso de los profetas que los están embaucando y engañando. que los están alienando y adormeciendo. Les dice:

No escuchen las palabras de los profetas que les profetizan. Los están embaucando. Les cuentan sus propias fantasías, no cosa de boca de Yahveh. Dicen a los que me desprecian "Yahveh dice: paz tendrán" y a todo el que camina en terquedad "no les sucederá nada malo".

$\mathrm{Y}$ en el verso 22 dice de los profetas que "si asistieron a mi consejo, hagan oír tni palabra a mi pueblo, y háganle tornar de su mal camino y de sus acciones malas". Coino se ve. Jeremías está interpelando a los profetas para que hagan oír la palabra de Dios al pueblo y lo hagan volver de su mal camino y de sus malas acciones.

En la confrontación con los falsos profetas, en 27-29, Jeremías llaina a los embajadores de los países vecinos, a Sedecías y a los sacerdotes y al pueblo entero, a no oír a sus profetas, adivinos, soñadores, augures ni hechiceros que les hablan diciendo: "No servirán al rey de Babilonia, porque cosa falsa les proletizan para alejarles de su suelo de modo que yo los arroje y perezcan" (Jr 27, 9-10). Para Jeremías, una de las cosas que está clara en esa discusión con los falsos proletas es que es profeta auténtico el que llama a la conversión, el que no aliena, el que habla desde una realidad que puede ser cambiada con la conducta humana, no desde el conformismo y las falsas esperanzas ( $c f r$. Jr 28). 
Y cuando envía la carta a los deportados en Babilonia (cfr. Jr 29), insiste en que todos los males que han venido y siguen viniendo sobre el pueblo se deben a que no han oído las palabras que Yahveh les ha enviado siempre y se han dejado llevar por palabras de profetas que no se convierten, sino que obran con fatuidad, cometen adulterio y fingen pronunciar palabras de Yahveh (cfr. Jr 29, 19.23). Parece, pues, que el único camino para salir de la situación es convertirse profundamente y no mantenerse adormecidos. Sólo así se puede salir adelante.

Al final de la actividad de Jeremías, cuando está en Egipto, donde ha sido llevado contra su voluntad, como la causa de todos los desastres últimos que van a venir sobre el pueblo de Judá, el pueblo sigue sin convertirse. Jeremías dice en esas circunstancias: "No se han compungido hasta la fecha, ni han temido ni andado en la Ley'y los preceptos que les propuse a ustedes y a sus padres" (Jr $44,10)$.

\section{Nueva oferta de alianza}

Tras la exigencia de conversión, como respuesta a las llamadas a salir del pecado, de la infidelidad, Jeremías presenta siempre como algo fundamental, relacionado con la conversión, la nueva oferta que Dios va haciendo de alianza; una alianza, por otra parte, que no es mera continuidad de la anterior, sino que es algo realmente nuevo.

Comenzando con su primera actividad, en Anatot, Jeremías recuerda a su pueblo destruido y sin muchas esperanzas su pasado de pecado y de infidelidad, lo llama después a la conversión (en el famoso poema de la conversión) y acaba con la nueva oferta de alianza, tal como aparece en Jeremías 4, 2: "Jurarías '¡Por vida de Yahveh!' con verdad, con derecho y con justicia”. Yahveh está ofreciendo una nueva situación en la que el pueblo de Dios recuperará la misión que Yahveh le ha dado, la de dar testimonio de Yahveh y conseguir así que los pueblos lo lleguen a conocer y a ser bendecidos por él -lo cual va unido a actitudes morales y de relaciones interhumanas, como son la verdad, el derecho y la justicia.

En las promesas de restauración de Israel, que siguen al poema de la conversión y que son como una nueva oferta de alianza, Yahveh afirma que la nueva alianza pasa por volver a formar el pueblo de Dios, con todas las repercusiones sociales que esto implica. Así lo dice en Jeremías 30, 3: “... haré tornar a los cautivos de mi pueblo Israel y les haré volver a la tierra que di a sus padres en posesión". Y en Jeremías 30, 7, habla de la angustia de aquel día, pero añade que es una angustia de la que "quedará salvo". $Y$ añade: "...mira que yo acudo a salvarte desde lejos y lu linaje desde el país de su cautiverio; volverá Jacob, se sosegará y estará tranquilo, y no habrá quien le inquiete, pues contigo estoy yo para salvarte" (Jr 30, 10-11). 
El profeta comienza, pues, presentando días de angustia y de pánico, a los cuales seguirá una situación de salvación. Las heridas de lsrael son incurables. Israel está desahuciado y no liene remedio su mal, siempre a causa de su gran pecado ( $c f i: 30,12 \mathrm{ss}$ ), pero a continuación Yahveh habla de que aquellos que han maltratado a su pueblo acabarán maltratados, despojados y saqueados. Habla también de la nueva suerte de su pueblo, de que Yahvch hará que tenga alivio, le curará sus llagas, pondrá la mirada en su ciudad, la que fue llamada por sus enemigos "la rechazada", "nuestra presa" y "no hay quien la busque". Y sigue con la descripción del regreso de los israelitas dispersos, la restauración y la reunión de todos ellos en la tierra:

He aquí que hago volver a los cautivos de Jacob y de sus mansiones me apiadaré; será reedificada cada ciudad sobre su montón de ruinas... los multiplicaré... serán sus hijos como antes, su comunidad ante iní estará en pie, y yo visitaré a todos sus opresores... Será su soberano uno de ellos... Y ustedes serán mi pueblo y yo seré sus Dios (cfr. Jr 30, 17-22).

En el capílulo 31 lodavía encontramos afirmaciones más importantes en esta línea de la nueva oferta de alianza.

En aquel tiempo... seré el Dios de todas las familias de Israel, y ellos serán mi pueblo... Halló gracia en el desierto el pueblo que se libró de la espada. va a su descanso Israel... Con amor eterno te he amado: por eso he reservado gracia para ti. Volveré a edificarte y serás reedificada, virgen de Israel; aún volverás a tener el adorno de tus adufes y saldrás a bailar entre gentes lestivas. Aún volverás a plantar viñas en los montes de Samaría... (vv. 1-5).

Y en los versos 7 y siguientes sigue invitando a proclamar que Yahveh ha salvado a su pueblo. Las palabras de Yahveh no pueden ser más significativas:

Miren que yo los traigo del país del norte, y los recojo de los confines de la lierra. Entre ellos, el ciego y el cojo, la preñada y la parida a una... Con Iloro partieron y con consuelos los devuelvo, los llevo a arroyos de agua por camino llano, en que no tropiecen. Porque yo soy para Israel un padre y Efraím es mi primogénito.

En Jeremías 31, 10 y siguientes, Yahveh invita a su pueblo a decir: "El que dispersó a Israel le reunirá y lo guardará cual un pastor su rebaño". Y el profieta da a continuación la razón:

Porque ha rescatado Yahveh a Jacob y le ha redimido de la mano de otros más fuertes. Vendrán y darán hurras en la cima de Sión y acudirán al regalo de Yahveh... y será su alma como huerto empapado, no volverán a estar macilentos. Entonces se alegrará la doncella en el baile, los mozos y los viejos disfrutarán, y cambiaré su duelo en regocijo y les consolaré y alegraré de su tristeza (J/ 31, 10-13). 
En el fragmento siguiente, Raquel, la madre de José y Benjamín (Israel), está desconsolada porque sus hijos ya no existen; pero Yahveh, le dice:

Reprime tu voz del lloro y tus ojos del llanto, porque hay paga para tu trabajo; volverán de tierra hostil, y hay esperanza para tu futuro; volverán los hijos a su territorio. Bien he oído a Efraím lamentarse: "Me corregiste y corregido fui, cual becerro no domado. Hazme volver y volveré, pues tú, Yahveh, eres mi Dios. Porque luego de desviarme, me arrepiento, y luego de darme cuenta me golpeo el pecho, me avergüenzo y me confundo luego. porque aguanto el oprobio de mi mocedad". ¿Es un hijo tan caro para mi Efraím, o niño tan mimado, que tras haberme dado tanto que hablar tenga que recordarlo todavía? Pues, en efecto se han conmovido mis entrañas por él; ternura hacia él no ha de faltarme (Jr 31, 16-20).

(No tomo ahora en cuenta algunos fragmentos, desde el verso 23 al verso 28 , que también hablan de restauración y reconstrucción, porque son adaptaciones posteriores a Judá de esta nueva oferta de alianza que Jeremías dirige a Israel en su primera actividad.)

El tema de la responsabilidad personal (Jr 31, 29-30) es también expresión de una nueva oferta de alianza, pues ahí Yahveh asegura que ya no ocurrirá más que los padres coman las uvas amargas y los hijos sufran la dentera, sino que cada persona será responsable de sus actos, así de sus pecados como de su conversión. Se trata, pues, de una nueva oferta de alianza para quien se convierta.

En esta primera actividad en su pueblo de Anatot, uno de los textos más emblemáticos en lo que se refiere a la nueva oferta de alianza es el de Jeremlas 31, 31-34, Veámoslo.

He aquí que vienen días en que yo pactaré con la casa de Israel una nueva alianza... Esta será la alianza que yo pacte con la casa de Israel, después de aquellos días: pondré mi Ley en su interior y sobre sus corazones la escribiré, y yo seré su Dios y ellos serán mi pueblo. Ya no tendrán que adoctrinar más el uno a su prójimo y el otro a su hermano, diciendo: "Conozcan a Yahveh", pues lodos ellos me conocerán del más chico al más grande cuando perdone su culpa, y de su pecado no vuelva a acordarme.

En este texto, Yahveh se compromele a pactar una nueva alianza, no consistente en el cumplimiento de una ley cada vez más perfeccionada y actualizada, sino en la interiorización de la ley por don de Yahveh, de modo que cada persona acluará movida por Yahveh mismo, desde el fondo de su corazón y todos tendrán una relación profunda con él y se sentirán plenamente reconciliados con él. Se trata, por tanto, de una auténtica nueva oferta de alianza, nacida del reconocimiento del pecado y de la aceptación de la relación prolunda con Yahveh. También en Jeremías 31, 35-37 se da una nueva oferta de 
alianza: Yahveh permanecerá siempre en la historia de la humanidad, tal como se ha comprometido a hacerlo.

En la segunda actividad, durante el reinado de Joaquín I, entre los años 609 y 598 , a las constantes llamadas a la conversión sigue de nuevo el compromiso de Yahveh a quedarse con su pueblo y a acompañarlo en el camino de la justicia y la solidaridad, el camino de la formación del nuevo pueblo. Y así, al "mejoren de conducta y de obras", sigue el "yo haré que se queden en este lugar...", y al "no fíen en palabras engañosas, diciendo: "itemplo de Yahveh, templo de Yahveh, templo de Yahveh es éste!' Porque si ... realmente hacen justicia mutua y no oprimen al inmigrante, al huérfano y la viuda (y no derraman sangre inocente en este lugar, ni andan en pos de otros dioses para su daño", sigue el "entonces yo me quedaré con ustedes en este lugar, en la tierra que di a sus padres desde siempre hasta siempre" (cfr. Jr 7, 3-7), recordándoles a continuación Yahveh lo que les mandó al sacarlos del país de Egipto, es decir, "escuchen mi voz, y yo seré su Dios y ustedes serán mi pueblo, y seguirán todo camino que yo les mandare, para que les vaya bien" ( $f f r$. Jr 7, 2l-23). La nueva oferta de alianza, pues, tiene total relación con la conducta de cada ser humano y de la comunidad entera, en donde la justicia y la solidaridad vayan a la par de la relación con Yahveh.

En Jeremías 26, cuando Baruc resume partes del discurso anterior, Yahveh encarga a Jeremfas que hable a todas las ciudades de Judá todas las palabras que Yahveh le ha mandado hablarles. Y Yahveh continúa ofreciendo un futuro para su pueblo: "Puede que oigan y se tome cada cual de su mal camino, y yo me arrepentiría del mal que estoy pensando hacerles por la maldad de sus obras" ( $\mathrm{J} r$ 26, 3).

A raiz de este discurso, Baruc narra el intento de acabar con Jeremías, a quien se le llega a juzgar, pidiendo la pena de muerte. En el mismo Jeremías 26, Baruc recoge lo que Jeremías dice para defenderse:

Yahveh me ha enviado a profetizar sobre esta Casa y esta ciudad todo lo que han oído. Ahora bien, mejoren sus caminos y sus obras y oigan la voz de 'Yahveh su Dios y se arrepentirá Yahveh del mal que ha pronunciado contra ustedes (Jr 26, 12-13).

En la tercera actividad vuelve a aparecer con fuerza la oferta de una nueva alianza. En el mensaje a la casa real de David, el profeta recuerda a los reyes cuál es su papel de servicio al pueblo. Deben apoyar la justicia, la paz y la solidaridad. Jeremías transmite este mensaje sobre todo al rey Sedecías cuando éste está a punto de entrar (593 a. C.) en una nueva coalición contra Babilonia, por presiones de otros países. Jeremf́as ve dicha entrada en la guerra como lo más terrible que le puede ocurrir a Judá; acabará mal. Por eso recuerda al rey sus obligaciones y el servicio que debe hacer. Le dice así en Jeremías 22, 4-5: 
Porque si ponen en práclica esta palabra [la de trabajar por el derecho y la justicia, la de delender a los indefensos y marginados, la de rechazar la violencial, entonces seguirán entrando por las puerlas de esta casa reyes sucesores de David en el trono, montados en carros y caballos, junto con sus servidores y su puchlo. Pero si no oyen ésta palabra... en ruinas parará esta casa.

Se condiciona una vez más la oferta de nueva alianza al cumplimiento de la voluntad de Dios. Y en Jeremías 23, 1-8, el profeta recrimina a los pastores que han dejado y han provocado que las ovejas se dispersen ("ustedes han (lispersado mis ovejas, las empujaron y no las atendieron", Jr 23, 2), y los aıncnaza con dureza, aunque, en último término, vuelve a ofrecer su alianza con cstas palabras:

Yo recogeré el resıo de mis ovejas de todas las tierras a donde las empujé, las haré Iornar a sus estancias, criarán y se multiplicarán. Y pondré al frente cle ellas pastores que las apacienten, y nunca más estarán medrosas ni asustadas, ni faltará alguna... suscitaré a David un germen justo: reinará un rey prudente, practicará el derecho y la justicia en la tierra. En sus días estará salvo Judá, e Isracl vivirá en seguro. Y éste es el nombre con que le llamarán "Yahveh, justicia nuestra" (Jr 23, 3-6).

Al parecer, esta nueva oferta de alianza es después actualizada y se aplica al retorno a la tierra, como se lee en Jeremías 23, 7-8:

... no se dirá más “¡Por vida de Yahveh, que subió a los hijos de Israel de Egipto!”, sino: "¡Por vida de Yahveh, que subió y trajo la simiente de la casa de Israel de las tierras del norte y de todas las tierras a donde los arrojara!". y habilarán en su propio suelo.

En el fondo, Yahveh sigue haciendo su nueva oferta de salvación y de nueva alianza cuando afirma que Babilonia invadirá el país, pero también que caerá y que, en último término, Judá vivirá. Así lo dice en Jeremías 25; 27-29. Recojamos algunos textos del capítulo 27:

... la nación que someta su cerviz al yugo de Babilonia y le sirva, yo la dejaré tranquila en su suelo y lo labrará y morará en él... [A Sedecías] Sometan sus cervices al yugo del rey de Babilonia, sírvanle a él y a su pueblo, y quedarán con vida... Sirvan al rey de Babilonia y quedarán con vida... Y si ellos son profetas y la palabra de Yahveh les acompaña, que conjuren, ea, a Yahveh Sebaot para que los objetos que quedaron en la casa de Yahveh, en la casa del rey de Judá y en Jerusalén no vayan a Babilonia (vv. 11-18).

En todos estos textos aparece con claridad que Dios sigue haciendo su oferta de salvación en aquellos momentos difíciles en los que, si el pueblo se mete en 
otra guerra contra Babilonia, les puede venir la ruina total. Dios está diciendo que, si su pueblo sigue la voluntad de Dios, puede vivir tranquilo en su suelo, puede labrar y cuidar el suelo, puede quedar con vida, puede evitarse dicha ruina.

En la disputa con el profeta Jananías ( $\mathrm{J} r 28$ ), Jeremías, frente a las promesas que hace aquél de que pronto van a volver los desterrados y que todos los objetos del templo serán devueltos por Babilonia, le hace ver que con su palabra conformista de esperanza en el pronto retomo y no de llamada a la conversión del pueblo, no está en la línea de la tradición profética, ya que ésta siempre se ha preocupado por intentar que el pueblo se convierta, tal como aparece en los versos 8 y 9 .

Y en la carta a los deportados a Babilonia, tal como nos narra el capítulo 29. en la que vuelve a avisar sobre los falsos profetas, Jeremías llama al pueblo en Babilonia a edificar casas y habitarlas, plantar huertos y comer sus frutos, tomar mujeres y engendrar hijos e hijas, y medrar alli, procurar el bien de la ciudad donde han sido deportados. Les vuelve a avisar contra los falsos profetas que hablan de una pronta recuperación de Judá. Pero también les dice que "al filo de curnplírsele a Babilonia setenta años", Dios los visitará y confirmará sobre ellos su favorable promesa de volverlos a Judá (cfr. Jr 29, 10).

Que bien me sé los pensamientos que pienso sobre ustedes, pensamientos de paz y no de desgracia, de darles un porvenir de esperanza. Me invocarán ustedes y vendrán a rogarme y yo les escucharé. Me buscarán y me encontrarán. cuando me soliciten de todo corazón; me dejaré encontrar de ustedes... devolveré sus cautivos, los recogeré de todas las naciones y lugares a donde los arrojé y los haré tomar al sitio de donde los hice que fuesen desterrados.

En este mismo contexto, cuando muchos piensan que Jerusalén resurgirá y acabará con Babilonia, Jeremías cuenta (cfr. Jr 24) la famosa visión de los dos cestos de higos, por medio de la cual quiere decir que Dios espera rehacer la historia con cl resto que está en Babilonia y no con los que han quedado en Jcrusalén, tras la primera deportación. El profeta habla de los higos malos, pero sobre todo de los higos buenos, los desterrados de Judá, que él echó de estc lugar, en los que él se interesará, pondrá su vista en ellos para su bien, los devolverá al país, los reconstruirá para no volver a destruirlos y los plantará para no arrancarlos, les dará un corazón nuevo para conocerlo y hará con cllos una nueva alianza ("pues ellos serán mi pueblo y yo seré su Dios"), y ellos volverán con lodo su corazón. Yahveh vuelve a ofrecer su alianza y nueva vida a los desterrados, ahora cuando nadie espera que haya futuro. Lo promete y se comprometc con ello.

En un contexto parecido, cuando la ciudad está a punto de cacr por segunda vez en manos de los enemigos babilonios, Jeremías descubre que Yahveh les 
está haciendo una nueva oferta de alianza para el futuro. Jeremías está en la cárcel. Viene su primo Janamel desde Anatot y lo exhorta a ejercitar el derecho de rescate del campo de Anatot y a comprarlo. Efectivamente, Jeremías compra el campo y comprende que Dios le quiere decir algo por medio de este suceso. $Y$ lo que comprende es que "todavía se comprarán casas y campos y viñas en esta tierra" (Jr 32,15). Jeremías lo ve como imposible y así se lo representa a Dios. Yahveh entonces le contesta:

Mira que yo soy Yahveh, el Dios de toda carne. ¿Habrá cosa extraordinaria para mí?... He aquí que yo pongo esta ciudad en manos de los caldeos y en manos de Nabuconosor... Pero así como he traido sobre este pueblo todo este gran perjuicio, así yo mismo voy a traer sobre ellos todo el beneficio que pronuncio sobre ellos, y se comprarán campos en esta tierra de la que dicen ustedes que es una desolación, sin personas ni ganados, y que está a merced de los caldeos; se comprarán campos con dinero (Jr 32, 27-29.42-44).

Lo mismo ocurre en Jeremfas 33. Tras decir que la ciudad va a caer en manos de los caldeos, añade:

He aqui que yo les aporto su alivio y su inedicina. Los curaré y les descubriré una corona de paz y seguridad. Haré tornar a los cautivos de Judá y a los cautivos de Israel y los reedificaré como en el pasado, y los purificaré de toda culpa que cometieron contra mr y perdonaré todas las culpas que cometieron contra mí y con que me fueron rebeldes. Jerusalén será para mí un nombre evocador de alegrá, será prez y ornato para todas las naciones de la tierra que oyeren todo el bien que voy a hacerle, y se asustarán y se estremecerán de tanta bondad como voy a concederle... Aún se oirá en este lugar, del que ustedes dicen que está abandonado, sin personas ni ganados, en todas las ciudades de Judá y en las calles de Jerusalén desoladas, sin personas ni habitantes ni ganados, voz de gozo y de alegría, la voz del novio y la voz de la novia, la voz de cuantos traigan sacrificios de alabanza a la casa de Yahveh diciendo "alaben a Yahveh Sebaot, porque es bueno Yahveh, porque es eterno su amor", pues haré tornar a los cautivos del país, y volverán a ser como antes... Aún habrá en este lugar abandonado de hombres y ganados y en lodas sus ciudades, dehesa de pastores que hagan acostarse a las ovejas... volverán a pasar ovejas ante la mano del que las cuente (Jr 33, 6-13).

(A partir de Jeremías 33, 14 siguen promesas más institucionales, referentes a un futuro en que los poderes reales y sacerdotales estarán unidos. No las comento aquí, pues parecen ser bastante posteriores y están relacionadas con Zacarías $4,1-14 ; 6,13$.)

Todo lo anterior ocurre en el momento en que Jerusalén está a punto de caer $y$ en que, a pesar de ello, Jeremías descubre que el mensaje de Yahveh es de 
esperanza para su pueblo. Como sabemos, la ciudad cayó en manos de Nabucodonosor y éste dejó en la zona a un gobernador judío, Godolías, al cargo de grupos sobre todo de campesinos. Este gobernador fue asesinado poco después por un tal Ismael, posiblemente apoyado por los amonitas. Tras dicho asesinato ( $c f r . \mathrm{Jr} 40,7 \mathrm{ss}$ ), cuando algunos van a consultar a Jeremías sobre lo que deben hacer, si quedarse en la tierra o huir de las posibles represalias de Nabucodonosor, Jeremías les responde, en su cuarta actividad, lo que él ha escuchado de Yahveh:

Si se quedan a vivir en esta tierra, yo les edificaré y no los destruiré, los plantaré y no los arrancaré... No teman al rey de Babilonia, que tanto les asusta... que con ustedes estoy yo para salvarlos y librarlos de su mano. Haré que se les tenga compasión y él se la tendrá y les devolveráa a su suelo... (Jr 42, $10-12$ ).

La oferta nueva de Dios para el futuro es condicionada en este caso a la obediencia o desobediencia del pueblo, a si se quedan en la tierra como Yahveh, por medio de Jeremías, les ordena o si huyen a Egiplo ( $c f r$. Jr 42, 13ss).

A lo largo de todos estos textos de las diferentes actividades de Jeremías ha ido quedando claro que la última palabra de Dios es una oferta de nueva alianza. Asimismo, que esta oferta hace referencia a una nueva relación del pueblo con Yahveh y a la relación interhumana y comunitaria de quienes forman su pueblo.

\section{Una oferta no aceptada: los padecimientos y dudas del profeta}

El éxito de esta oferta supone la disposición, en quienes la reciben, a camhiar las cosas, a trabajar por ese sueño y proyecto de Dios para la humanidad. Frecuentemente, esto no suele ocurrir, y los responsables y conductores de la sociedad no actúan de esa manera. De ahí que la respuesta a esta oferta sea muchas veces la incomprensión y la persecución de quien se alreve a proponerla de parte de Dios. En Jeremías, esto es palpable y manifiesto.

Durante la primera actividad, Jeremías pronuncia palabras agradables para un pueblo desesperado, desiruido y sin mucha ilusión por el futuro, pero, en su segunda actividad, comienza a encontrarse con fuerte oposición y persecución. Cuando se atreve a decir que el templo de Jerusalén se ha convertido en cueva de ladrones, en la cual se cobijan personas injustas, opresoras y asesinas, y que, por tanto, va a quedar en ruinas como el antiguo santuario de Silo, se produce un gran revuelo. El alboroto es de tal magnitud que la multitud, instigada por los sacerdotes y los profetas del templo, agarra a Jeremías e intenta lincharlo. Jeremías se salva gracias a que algunas personas de cierta influencia consiguen llevar el caso a juicio.

Jeremías 26 narra que se constituye el tribunal judicial formado por los jueces (jefes de Judá y pueblo) y acusadores (sacerdotes y profetas del templo). 
Estos están tan cerrados a las llamadas a la conversión de Jeremías y a la profundización en lo que conlleva dicha conversión y experiencia de fe en las relaciones interhumanas, que piden con insistencia la pena de muerte. El profeta se salva de la muerte en esta ocasión gracias a que algunas personas de peso y autoridad moral saben mostrar en el tribunal que en la historia se ha dado el caso de otros profetas que también han hablado muy críticamente sobre las instituciones (como Sión o el sacerdocio), y las autoridades no sólo no los eliminaron, sino que les hicieron caso e iniciaron el camino de la conversión.

En cualquier caso. es importante el final del capítulo 26 . Se dice allí que, contemporáneamente a Jeremías, surgi6 otro profeta que hablaba de parte de Yahveh de modo semejante al de Jeremíns. El rey Joaquín I lo condena a muerte y consigue, tras la extradición de dicho profeta por parte de Egiplo, ejecutar su decisión con sus propias manos. El dato ha sido recogido por Baruc, posiblemente para mostrar que la resistencia a la llamada a la conversión puede llegar hasta eliminar al profeta. La nueva oferta de alianza no interesa a quienes tienen su idea propia de salvación y a quienes la conversión a Dios les supondría cambiar sus actitudes y acciones egoístas por unas relaciones solidarias y generosas con el prójimo.

La persecución provoca en Jeremías inseguridades, dudas y crisis de fe, pero a pesar de todo continúa (cfr. Jr II, 18-12,6). Sigue insistiendo no sólo en la desirucción del templo, sino en la destrucción de la ciudad y de todas sus instituciones. Jeremías, además, da más fuerza todavía a sus amenazas con el acto simbólico del cántaro roto, tal como se nos narra en Jeremías 19, I-20, 6. Con toda solemnidad, reúne a algunos ancianos del pueblo y algunos sacerdote en la pucrta de las Tejoletas, quiebra contra el suelo un cántaro de cerámica y dice: "Asimismo quebrantaré yo [se refiere a Yahveh] a este pueblo y a csta ciudad, como quien rompe un cacharro de alfarería, que ya no tiene arreglo" (Jr 19. 1I). "He aquí que yo traigo a esta ciudad y a todos sus alrededores toda la calamidad que he pronunciado contra ella, porque ha atiesado su cerviz, desoyendo mis palabras" $(\mathrm{Jr} 19,15)$. Obviamente, la reacción del poder no se deja esperar, tal como nos narra Baruc, en Jeremías 20, Iss. El inspector de policía del templo manda apresar a Jeremías, lo tortura y lo golpea, y lo deja lihre. pero con la condición de que no siga hablando contra el templo y la ciudad. De nuevo Jeremías, frente a la oposición y la resistencia Jel poder. cae en el desánimo y eslá a punto de rendirse (cfr. el resto de las confesiones de Jeremias).

Pcro no es así. Jeremías sale robustecido y dicta a su compañero Baruc llaınadas a la conversión y palabras de amenaza a causa de la infidelidad y cerrazón del pueblo de Judá. En Jeremías 36 se narra cómo reacciona el poder en general y el rey en particular ante eslas palabras del proleta, escritas y leídas en público. Joaquín l destruye el escrito, quemándolo en el luego y ordena la 
"búsqueda y captura" de Jeremías y Baruc. Estos consiguen escapar, pero ha quedado bien patente la resistencia ante la nueva oferta de alianza que hace Jeremías, que debe pasar por el arrepentimiento, la conversión y el cambio. En resumen, el rey Joaquín I hace todo lo posible por silenciar al profeta cuando éste llama a la conversión y al cambio radical. Con ello entramos a la iercera actividad, entre los años 593 y 588 a. C.

El sucesor de Joaquín I ha quedado como rey en Jerusalén, vasallo del emperador babilonio. En esos años se dan varios intentos de rebelión contra Nabucodonosor; incluso llega a producirse en Jerusalén una reunión clandestina de diferentes pueblos vecinos y Judá para formar una coalición (cfr: $\mathrm{Jr}$ 27). Entre otros, algunos profetas animan a la formación de dicha coalición. Jeremías, viendo claro que tal coalición y rebelión contra Babilonia llevaría a la autodestrucción de Judá y Jerusalén, se opone con todas sus fuerzas a dichos profetas y los acusa de hablar falsedad, de no atender a los signos de los liempos y a la realidad de las cosas. Jananías se opone entonces con todas sus fuerzas a Jeremías, rompiendo simbólicamente el yugo de madera que lleva sobre su cuello y aquél que representa a Babilonia ( $c f r$. Jr 28). Algunos proletas quc están con el pueblo, en Babilonia, ante una carta que reciben de Jcremías, en la cual les dice que no lleva a ninguna parte en aquel momento una rebelión contra Babilonia, lo denuncian por carta ante el inspector de policía del templo. incitándolo a apresar a "aquel loco" y a hacer callar como sea a quien, según ellos, se dedica a desanimar al pueblo exhortándolo a prepararse para un largo exilio y una larga situación de dominio babilonio (cfr. Jr 29). De nuevo. la oposición al mensaje realista de Jeremías.

A pesar de todo, estallan la rebelión y la guerra. Nabucodonosor viene contra Judá y Jerusalén y ataca con dureza. El hecho de que no pueda conquistar rápidamente la capital sino que, por diferentes circunstancias, haya momentos en que parece que el emperador babilonio se debilita y es incapaz de dominar la situación, da fuerzas a los enemigos de Jeremías y amigos de la guerra, y esıo los lleva a perseguir con más fuerza al profeta, quien lo único que prelende es que su pueblo no acabe de caer en manos de los babilonios, sino que espere a mejores circunstancias para su salvación.

En Jeremías; $34,37-39$ se nos narra la reacción de los minisıros del rey Sedecías contra Jeremías por hablar en estos términos. Piden al rey que lo aprese, que lo torture, que lo condene a muerte y que ejecute la sentencia. Queda claro, en esos capítulos, que no se trata de un juego. Se trata de acubar con la palabra del profeta. Los que detentan el poder no aceptan la propuesta dc Jeremias de vivir como pueblo de Dios en aquella situación de crisis internacional. El no hacer caso de dichas palabras proféticas lleva a la caída y destrucción de Jerusalén, la capital de Judá, a la prohibición de reconstruir 
Jerusalén y vivir allí, y a la imposición de un gobernador judío, Godolías, por parte de Nabucodonosor, en el territorio de Judá.

Cuando Yahveh, por medio de Jeremías, en la cuarza actividad del profeta, ofrece a su pueblo nueva vida, si se quedan en la tierra tras el asesinato de Godolías a manos de Ismael, los que están al frente del pueblo en aquel ınomento, Azarías, hijo de Hoshaías, Yojanán, hijo de Caréaj, y otros hombres insolentes reaccionan de mala manera, llamando mentiroso a Jeremías (cfr. Jr 43. 2-3) y acusándolo de pretender, azuzado por Baruc, hijo de Neriyías, ponerlos en manos de los babilonios. Baruc $(43,4 s s)$ cuenta esta acción, frente a las palabras de Jeremías:

Además, ni Yojanán, hijo de Caréaj, ni ninguno de los jefes de las tropas, ni nadie del pueblo escuchó la voz de Yahveh que mandaba quedarse en lierra de Judá; antes bien... tomaron consigo a todo el resto de Judá... a hombres, mujeres, niños, a las hijas del rey y a toda persona que Nebuzaradán, jefe de la guardia, había dejado en paz con Godolías... y también al profeta Jeremías y a Baruc. hijo de Neriýas, y entrando en la lierra de Egiplo - pues desoyeron la voz de Yahveh-. se adentraron hasta Tafnis.

Jeremías no tiene más remedio que pronunciar su palabra ante este hecho. Obrando así, dice, lo que van a conseguir es que Babilonia los persiga hasta Egipto y los haga prisioneros allí. Y ante las amenazas de Jeremías contra sus compalriolas que, ya en Egiplo, se dedican a quemar incienso a otros dioses y a adaplarse a las costumbres que éslos exigen, aquéllos le responden:

En eso que nos has dicho en nombre de Yahveh, no te hacemos caso, sino que cumpliremos precisamente cuanto tenemos prometido, que es quemar incienso a la Reina de los Cielos y hacerle libaciones, como venimos haciendo nosotros y nuestros padres, nuestros reyes y nuestros jefes en las ciudades de Judá y en las calles de Jerusalén, que nos hartábamos de pan. éramos felices y ningún mal nos sucedía... (Jr 44, 16-17).

Según dice la tradición judía, sus compatriotas no se conforman con oponerse al profeta, sino que acaban asesinando a Jeremías, porque les resultó inolesto y los inquietó demasiado.

\section{Conclusión}

Tras analizar las actividades del profeta Jeremfas, entre los años 628 y 585 a. C., tanto en los territorios del antiguo reino de Israel, primero, como en el reino de Judá y en Egiplo, después, se puede concluir que el punto de partida de su predicación es la conslatación y la denuncia del pecado y de la infidelidad contra Dios, que se traduce siempre en la injusticia y la agresión contra el prójimo. 
A este inicio sigue en el profeta la constante llamada, de parte de Dios, a la conversión, una conversión que no puede separar el ámbito de la rclación con Dios del de la relación con el prójimo; una conversión que se maniliesta en la lïdelidad, en la justicia, en la fraternidad, en la solidaridad, en la comunión, en el amor.

Prolundamente enlazada con esta llamada a la conversión están la oferta y la promesa que, por medio del profeta, hace Yahveh mismo de una nueva alianza. de una nueva siluación, de una utopía a realizar a lo largo de la vida de cada ser humano y del conjunto del pueblo de Dios. Yahveh mismo se compromete a acompañar al ser humano en esta difícil tarea, que supone, en último término, la reconciliación profunda entre Yahveh y cada ser humano, y entre todas las personas que forman la sociedad.

Tal novedad y tal sueño de Yahveh, sin embargo, no se pueden abrir camino sin resistencias y obstáculos. Así lo vive Jeremias y así lo manifiesta su libro: trabajar por un mundo convertido, reconciliado y nuevo le cuesta a Jeremías la oposición constante, la incomprensión dolorosa, aun de las personas más cercanas, y la persecución a muerte. Es notable, sin embargo, la fuerte resistencia de la cual es capaz un personaje tan tímido, tan débil, tan lleno de dudas y perplejidades como Jeremías. Todo ello no se puede explicar si no es por el Espíritu de Yahveh que lo llena en medio de sus crisis y que lo va seduciendo para ponerse al servicio de la causa de la conversión y la reconciliación deseadas por Dios.

No quiero acabar, como decía al principio, sin mencionar que Jeremías reaparece hoy día en otros muchos profetas que, como Monseñor Oscar Arnulfo Romero de El Salvador, saben captar que nuestro mundo tan desangrado por el pecado, la injusticia, la desigualdad, la marginación, la muerte violenta de los inocentes, necesita palabras que llamen con insistencia a conversión, a lidelidad, a justicia, a pacilicación, a solidaridad, para hacer realidad así el proyecto y el sucño de Dios. superando los inevitables miedos, inseguridades, dudas, resistencias y persecuciones a muerte. Lo importante es dejarse convencer por el Espírilu, como Jcremías y todos los profetas que han existido y existen en la humaniJad, de que siempre "es posible regresar a Dios, al hermano y a la hermana. para reconciliarse profundamente". 